\title{
FAKTOR RISIKO PENYAKIT JANTUNG PADA MASYARAKAT DI POS PEMBINAAN TERPADU (POSBINDU) PUSKESMAS CIBEUREUM
}

\author{
Dian Saraswati*1,Nur Lina ${ }^{2}$ \\ ${ }^{1,2}$ Universitas Siliwangi,Kota \\ Tasikmalaya/Provinsi Jawa Barat Jurusan \\ KesehatanMasyarakat, FIK UNSIL e- \\ mail:*diansaraswati@ unsil.ac.id,
}

\begin{abstract}
ABSTRAK
Penyakit jantung koroner atau PJK, terjadi akibat adanya plak di dalam dinding arteri koroner yang menyebabkan aliran darah ke otot jantung berkurang yang disebut iskemia. Tujuan penelitian ini adalah menganalisis hubungan jenis kelamin, umur, tekanan darah, Indeks Massa Tubuh (IMT) dan aktifitas fisik dengan risiko menderita penyakit jantung berdasarkan skor kardiovaskuler Jakarta. Desain penelitian yang digunakan adalah cross sectional. Populasi adalah peserta Posbindu di wilayah kerja Puskesmas Cibeureum Kota Tasikmalaya dengan jumlah 163 orang. Jumlah sampel dihitung berdasarkan rumus Lemeshow berjumlah 115 orang. Temuan ini membuktikan hubungan jenis kelamin, umur, tekanan darah, Indeks Massa Tubuh (IMT) dan aktifitas fisik dengan risiko menderita penyakit jantung berdasarkan skor kardiovaskuler Jakarta. Seharusnya dilakukan penanganan secara menyeluruh dengan pendekatan five level prevention, yang meliputi promosi kesehatan, diagnosis dini dengan penghitungan IMT, tekanan darah dan pengobatan yang cepat dan tepat, pembatasan kecacatan bagi skor risiko tinggi

Kata Kunci: Faktor Risiko, skor kardiovaskuler Jakarta
\end{abstract}

\begin{abstract}
Coronary heart disease, or CHD, occurs due to plaque in the walls of the coronary arteries which causes reduced blood flow to the heart muscle called ischemia. The purpose of this study was to analyze the relationship of gender, age, blood pressure, Body Mass Index (BMI) and physical activity with the risk of suffering from heart disease based on Jakarta cardiovascular scores. The research design used was cross sectional. The population was Posbindu participants in the working area of Cibeureum Health Center in Tasikmalaya City with a total of 163 people. The number of samples is calculated based on the Lemeshow formula of 115 people. This finding proves the relationship of sex, age, blood pressure, Body Mass Index (BMI) and physical activity with the risk of suffering from heart disease based on Jakarta cardiovascular scores. Thorough handling should be carried out with a five-level prevention approach, which includes health promotion, early diagnosis by calculating BMI, blood pressure and prompt and appropriate treatment, limiting disability for high risk scores
\end{abstract}

Keywords: Risk Factors, Jakarta cardiovascular scores

(C) 2020 - Dian Saraswati, Nur Lina Under the license CC BY-SA 4.0 


\section{Gorontalo Journal Health and Science Community}

Vol : 4, No.1,April 2020

\section{PENDAHULUAN}

Penyakit jantung koroner atau PJK, terjadi akibat adanya plak di dalam dinding arteri koroner yang menyebabkan aliran darah ke otot jantung berkurang yang disebut iskemia. Penyempitan arteri koroner dari waktu ke waktu akan membatasi suplai darah ke bagian otot jantung. Penyempitan arteri juga bisa berlangsung akut, akibat plak dan terbentuknya trombus atau gumpalan darah. Pembentukan plak dimulai pada masa kanak-kanak, sehingga pada masa remaja, plak akan terbentuk sampai seumur hidup ${ }^{1 .}$

Data WHO tahun 2015 menunjukkan bahwa 70\% kematian di dunia disebabkan oleh Penyakit Tidak Menular (39,5 juta dari 56,4 kematian). Dari seluruh kematian akibat Penyakit Tidak Menular (PTM) tersebut, 45\% nya disebabkan oleh Penyakit jantung dan pembuluh darah, yaitu 17.7 juta dari 39,5 juta kematian. Badan Penelitian dan Pengembangan Kesehatan merilis hasil Riset Kesehatan Dasar atau Riskesdas 2018. Salah satu temuan yang menjadi perhatian adalah meningkatnya prevalensi penyakit tidak menular yaitu penyakit jantung koroner. Prevalensi Penyakit Jantung berdasarkan diagnosis dokter di Indonesia sebesar 1,5\% sedangkan prevalensi Penyakit Jantung di Provinsi Jawa Barat (1,6\%) lebih tinggi jika dibandingkan dengan prevalensi penyakit jantung secara nasional ${ }^{2}$.

Kota Tasikmalaya adalah salah satu kota di Propinsi Jawa Barat dengan angka kejadian penyakit jantung koroner yang tinggi. Menurut data rekam medis RSUD dr. Soekardjo kota Tasikmalaya tahun 2018 Penyakit jantung masih menempati 10 urutan terbesar. Penyakit jantung menempati urutan pertama untuk pasien yang menjalani rawat inap yaitu sebanyak 694 kasus dan urutan ke empat untuk pasien yang menjalani rawat jalan sebanyak 836 kasus $^{3 .}$

Target SDGs 3.4 menyerukan pengurangan sepertiga kematian dini dari penyakit kardiovaskuler pada tahun 2030, dan merupakan perpanjangan dari target kematian penyakit tidak menular global. Seluruh komponen bangsa baik pemerintah, swasta maupun masyarakat harus ikut berpartisipasi dan mendukung upaya pencegahan dan pengendalian faktor risiko PJK, sehingga angka kesakitan, kematian dan kecacatan karena PJK dapat diturunkan. Beberapa serangan jantung terjadi secara mendadak. Tetapi kebanyakan mulai perlahan, dengan rasa sakit ringan atau tidak nyaman seperti diremas, rasa kenyang atau sakit, ketidaknyamanan di area lain dari tubuh bagian atas pada satu atau kedua lengan, punggung, leher, rahang atau perut yang berlangsung lebih dari beberapa menit - atau mungkin hilang dan kemudian kembali. ${ }^{4}$

Penyakit jantung dan pembuluh darah dapat dicegah dengan mengendalikan faktor risiko, seperti merokok, diet yang tidak sehat, kurangnya aktivitas fisik dan konsumsi alkohol, agar tidak terjadi hipertensi, obesitas, kolesterol tinggi dan diabetes mellitus yang merupakan penyakit antara sebelum terjadinya penyakit jantung koroner. Apabila faktor risiko dapat diketahui maka akan lebih mudah untuk dilakukannya tindakan pencegahan. Penyakit jantung koroner stabil tanpa gejala biasanya diketahui dari skrining. Salah satu skrining risiko PJK di Indonesia dilakukan dengan cara stratifikasi faktor risiko sehingga dapat memperkirakan kejadian penyakit kardiovaskular 10 tahun ke depan ${ }^{5}$

Tujuan penelitian ini adalah menganalisis hubungan jenis kelamin, umur, tekanan darah, Indeks Massa Tubuh (IMT) dan aktifitas fisik dengan risiko menderita penyakit jantung berdasarkan skor kardiovaskuler Jakarta. Manfaat dari penelitian ini diharapkan dapat memberikan informasi faktor risiko kejadian Penyakit Jantung Koroner di masyarakat khususnya pada peserta pos pembinaan terpadu penyakit tidak menular (Posbindu PTM) serta dapat dijadikan sebagai acuan dilakukannya tindakan pencegahan terjadinya Penyakit Jantung Koroner. Posbindu Cibeureum digunakan sebagai lokasi penelitian dengan pertimbangan Posbindu Cibeureum merupakan salah satu Posbindu yang aktif di wilayah kerja Dinas Kesehatan Kota Tasikmalaya. 


\section{Gorontalo Journal Health and Science Community}

Vol : 4, No.1,April 2020

\section{METODE}

Desain penelitian yang digunakan dalam penelitian ini adalah Cross sectional. Populasi adalah peserta Posbindu di wilayah kerja Puskesmas Cibeureum Kota Tasikmalaya dengan jumlah 163 orang. Sampel diambil secara proporsional dari 5 posbindu aktif di wilayah kerja Posbindu Puskesmas Cibeureum yaitu Posbindu yang terdapat di kelurahan Awipari, Ciakar, Kersanagara, Margabakti dan Setiyajaya. Sampel dihitung dengan rumus Lemeshow

$$
n=\frac{z^{2}{ }_{1} \alpha_{2} p(1-p) N}{d^{2}(N-1)+z^{2}{ }_{1} \alpha_{2} p(1-p)}
$$

$\mathrm{n}=114.6515$ dibulatkan menjadi 115 orang

Variabel bebas dalam penelitian ini adalah jenis kelamin, umur, IMT, tekanan darah dan aktifitas fisik, sedangkan variabel terikat dalam penelitian ini adalah Skor Kardiovaskular Jakarta. Pasien dinilai stratifikasi risikonya berdasarkan Skor Kardiovaskular Jakarta ${ }^{5}$. Skor Kardiovaskular Jakarta merupakan modifikasi penentuan risiko penyakit kardiovaskular yang mengacu pada studi Frammingham berdasarkan jenis kelamin, umur, tekanan darah (kritera JNC-VI), merokok, diabetes mellitus, indeks massa tubuh, dan aktivitas fisik mingguan, dengan tingkat sensitifitas (77,9\%) dan spesifisitas yang tinggi yaitu $90 \%$, nilai prediksi positif sebesar 92,2\% dan nilai prediksi negatif 72,8\% terhadap skoring studi Framingham. Hasil penghitungan skor risiko (-7)-1 berarti risiko rendah (risiko kardiovaskuler $<10 \%$ ), 2-4 artinya risiko sedang (risiko kardiovaskuler $10-20 \%$ ) dan $>5$ risiko tinggi (risiko kardiovaskuler $>20 \%)^{6}$

Jenis kelamin, umur, IMT, tekanan darah dan aktifitas fisik dikumpulkan dengan metode WHO Steps yaitu meliputi wawancara, pengukuran fisik dan pemeriksaan laboratorium. Pengolahan data diawali dengan melakukan editing, koding, entri dan cleaning data. Analisis univariat untuk mengetahui frekuensi dan distribusi nilai masing-masing variabel penelitian. Analisis bivariat antara variabel dependen (skor kardiovaskuler Jakarta) dengan variabel independen (jenis kelamin, umur, IMT, tekanan darah dan aktifitas fisik). Uji statistik korelasi range spearman digunakan untuk menguji umur, IMT, dan tekanan darah dengan risiko menderita penyakit jantung berdasarkan skor kardiovaskuler Jakarta dan Chi square untuk menguji hubungan jenis kelamin dan aktifitas fisik dengan risiko menderita penyakit jantung koroner.

\section{HASIL DANPEMBAHASAN}

\subsection{Analiasis Univariat}

Puskesmas Cibeureum adalah Puskesmas yang merupakan Unit Pelaksana Teknis (UPTD) dinas Kesehatan kota Tasikmalaya. Posbindu yang terdapat di wilayah kerja Puskesmas Cibeureum sebanyak 11 Posbindu, namun posbindu yang aktif melakukan kegiatan hanya 5 posbindu. Sampel diambil secara proporsional random sampling dari peserta Posbindu aktif.

Tabel 1 Data Statistik PJK di PosbinduPuskesmasCibeureum2019

\begin{tabular}{ll}
\hline Data Statistik Skor PJK & Nilai \\
\hline Skor minimum & -2 \\
Skor Maksimum & 10 \\
Rata rata skor & 4.7 \\
Standar deviasi & $\underline{2.54}$ \\
\hline
\end{tabular}

Tabel2DataKategoriSkorKardiovaskulerdiPosbinduPuskesmasCibeureum2019

\begin{tabular}{ccc}
\hline Kategoriskor risiko PJK & Jumlah & Persentase \\
\hline Tinggi $(>20 \%)$ & 71 & 61.7 \\
Sedang $(10-20 \%)$ & 30 & 26.1 \\
Rendah $(<10 \%)$ & 14 & 12.2 \\
\hline Total & 115 & 100.0 \\
\hline
\end{tabular}


Hasil penghitungan skor risiko menderita penyakit jantung berdasarkan skor risiko kardiovaskuler Jakarta didapatkan Skor Kardiovaskuler paling rendah -2, paling tinggi 10 dan nilai rata rata skor kardiovaskuler sebesar 4.7 dengan standar deviasi 2.54. Sebesar $61.7 \%$ responden mempunyai kategori risiko PJK yang tinggi berdasarkan hasil pengukuran skor kardiovaskuler Jakarta. Sebagian besar responden $(89.5 \%)$ berjenis kelamin perempuan. Rata rata umur responden adalah 53 tahun, dengan umur paling muda 45 tahun dan umur responden paling tua 61 tahun. Rata rata Indeks Massa Tubuh Responden adalah 26. IMT paling rendah adalah 18.7 dan IMT paling tinggi 46.9. Rata rata tekanan darah diastolik responden adalah $85 \mathrm{mmHg}$ dengan tekanan darah diastolik paling rendah $63 \mathrm{mmHg}$ dan tekanan darah diastolik paling tinggi $110 \mathrm{mmHg}$. Tekanan darah sistolik rata rata responden adalah $134,89 \mathrm{mmHg}$ sedangkan tekanan darah diastolik rata rata responden adalah $85.58 \mathrm{mmHg}$. Sebanyak $64 \%$ responden memiliki aktifitas fisik yang rendah.

3.2 Analisis Bivariat

3.2.1 Hubungan jenis kelamin dan skor risiko PJK

Hasil analisis bivariat antara jenis kelamin dan skor risiko PJK menggunakan uji Chi square dapat dilihat pada tabel 1. Risiko PJK tinggi lebih banyak ditemukan pada responden perempuan ( dibandingkan pada laki laki, sedangkan risiko PJK rendah lebih banyak didapatkan pada laki laki dibandingkan perempuan.

Tabel 3. Hubungan Jenis Kelamin dengan Skor Risiko PJK pada Responden di Posbindu wilayah Kerja Puskesmas Cibeureum Tahun 2019

\begin{tabular}{lccccc}
\hline Jenis & \multicolumn{3}{c}{ Kategori risiko PJK } & Total & P Value \\
\cline { 2 - 5 } Kelamin & $\begin{array}{c}\text { tinggi } \\
(>20 \%)\end{array}$ & $\begin{array}{c}\text { sedang } \\
(10-20 \%)\end{array}$ & $\begin{array}{c}\text { rendah } \\
(<10 \%)\end{array}$ & & \\
\cline { 2 - 5 } & $\mathrm{n}(\%)$ & $\mathrm{n}(\%)$ & $\mathrm{n}(\%)$ & $\mathrm{n}(\%)$ & \\
\hline Laki Laki & $2(16.7 \%)$ & $3(25.0 \%)$ & $7(58.3 \%)$ & $12(100.0 \%)$ & 0.00 \\
Perempuan & $69(67 \%)$ & $27(26.2 \%)$ & $7(6.8 \%)$ & $103(100.0)$ & \\
\hline Total & $71(61.7 \%)$ & $30(26.1 \%)$ & $14(12.2 \%)$ & $115(100 \%)$ & \\
\hline
\end{tabular}

Uji kebermaknaan Chi square dengan tabulasi silang antara jenis kelamin dan risiko PJK memberikan hasil sebagai berikut uji statistiknya bermakna $(\mathrm{p}=0,000)$. Artinya ada hubungan antara jenis kelamin dan skor risiko PJK.

\subsubsection{Hubungan umur dengan risiko menderita penyakit jantung berdasarkan skor kardiovaskuler} Jakarta.

Hasil uji statistik korelasi range spearman didapatkan $\mathrm{P}$ value sebesar 0.007 . Hal ini menunjukkan ada hubungan antara umur dengan skor risiko PJK pada peserta Posbindu Puskesmas Cibeureum
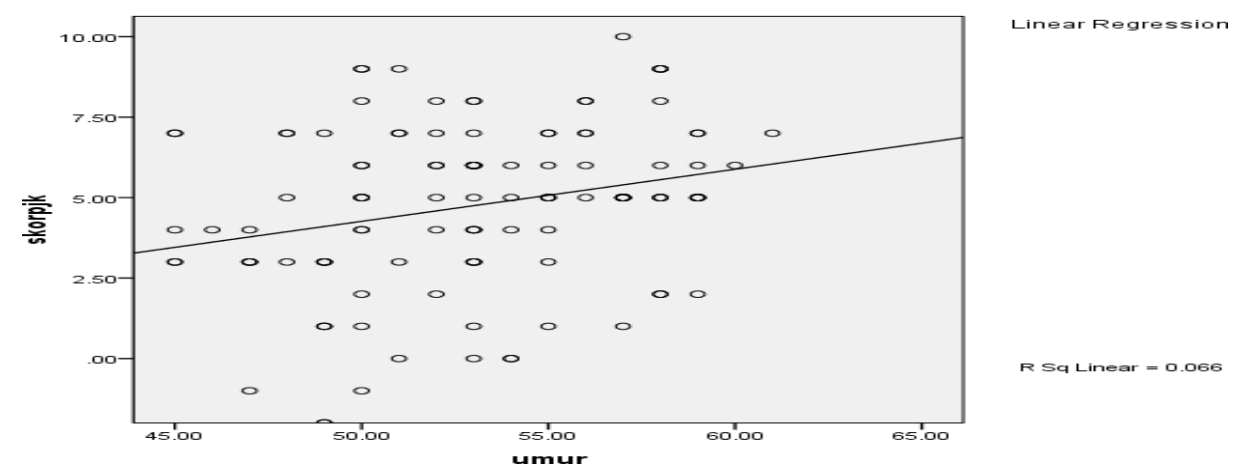

Gambar 1 Hubungan Umur dengan Skor PJK di Posbindu Wilayah Kerja Puskesmas Cibeureum Tahun 2019

Nilai koefisien korelasi sebesar 0.252 artinya hubungan berkorelasi lemah. Arah korelasi positif yang artinya semakin tinggi umur, semakin tinggi skorrisiko PJK. 


\section{Gorontalo Journal Health and Science Community}

Vol : 4, No.1,April 2020

3.2.3 Hubungan Indeks Massa Tubuh (IMT) dengan risiko menderita penyakit jantung berdasarkan skor kardiovaskuler Jakarta.

Ada hubungan korelasi antara Indeks Massa Tubuh dengan skor risiko PJK.
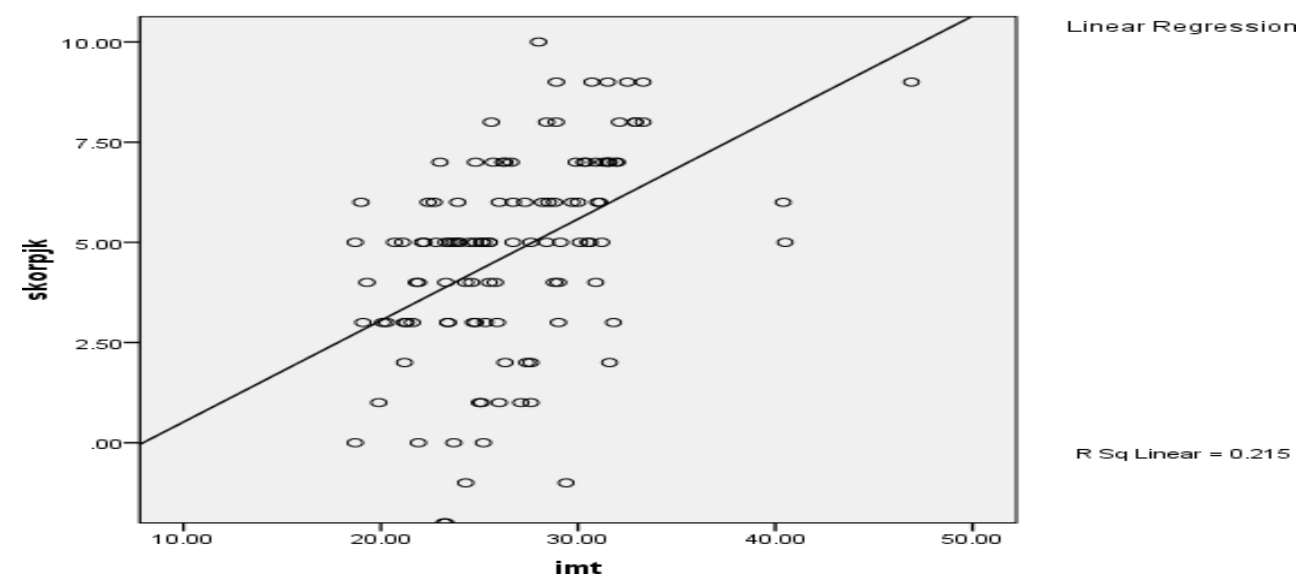

Gambar 2 Hubungan IMT dan Skor PJK di Posbindu Wilayah Kerja Puskesmas Cibeureum Tahun 2019

Hasil uji statistik korelasi range spearman didapatkan nilai $\mathrm{P}$ value sebesar 0.000 yang artinya ada hubungan korelasi antara Indeks Massa Tubuh dengan skor risiko PJK, dengan nilai koefisien korelasi positif sebesar 0.519 yang artinya hubungan berkorelasi kuat. Semakin tinggi Indeks massa tubuh semakin tinggi skor risiko PJK.

3.2.4 Hubungan tekanan darah dengan risiko menderita penyakit jantung berdasarkan skor kardiovaskuler Jakarta.

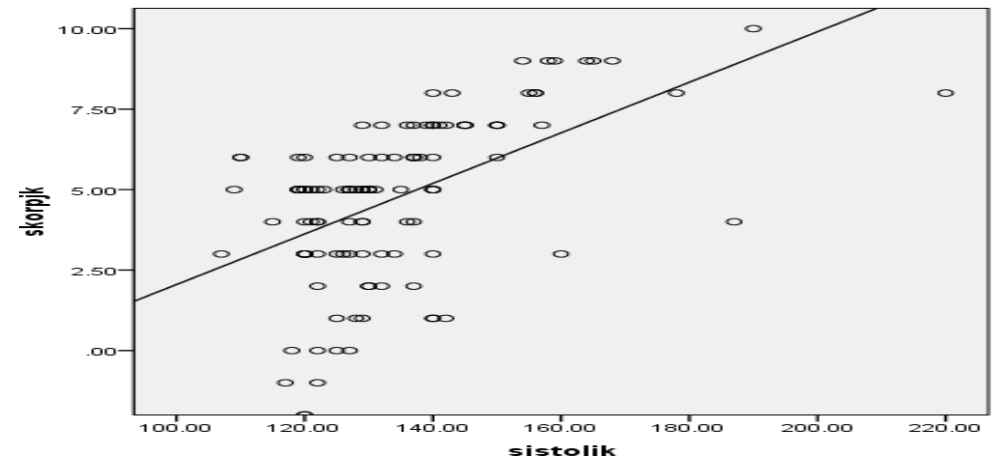

Gambar 3 Hubungan Tekanan Darah Sistolik dengan Skor PJK di Posbindu Wilayah Kerja Puskesmas Cibeureum Tahun 2019

Hasil Uji statistik korelasi range spearman hubungan antara tekanan darah sistolik dan skor PJK didapatkan nilai $\mathrm{P}$ sebesar 0.00 dan nilai koefisien korelasi sebesar 0.566 yang artinya ada hubungan kuat antara tekanan darah sistolik dengan skor risiko PJK dengan arah hubungan positif yang artinya semakin tinggi tekanan darah sistolik semakin tinggi risiko menderita penyakit jantung koroner. 


\section{Gorontalo Journal Health and Science Community}

Vol : 4, No.1,April 2020

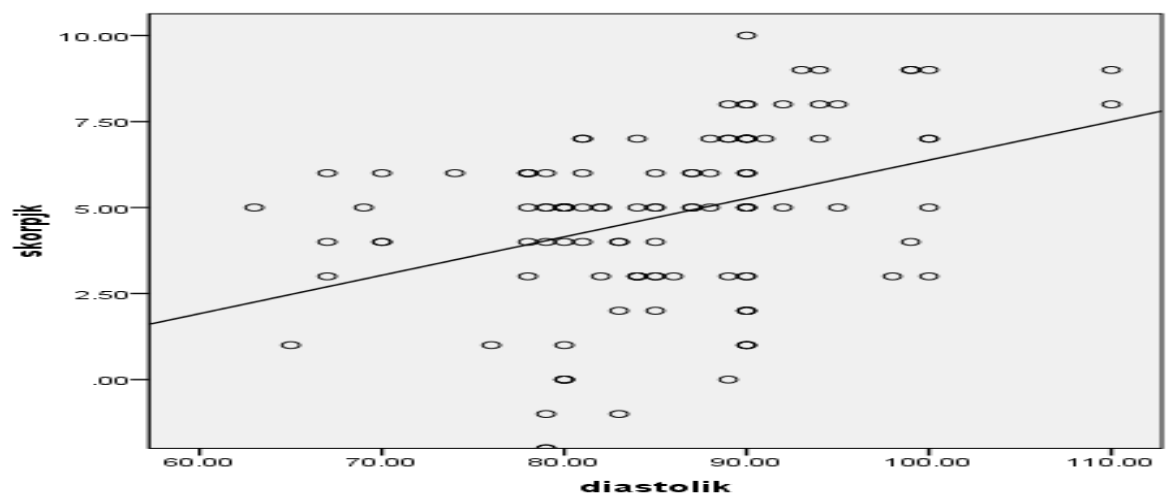

Gambar 4 Hubungan antara Tekanan Darah Diastolik dangan skor PJK di Posbindu Wilayah Kerja Puskesmas Cibeureum Tahun 2019

Hasil Uji statistik korelasi renge spaerman didapatkan nilai $\mathrm{p}$ sebesar 0.000 yang artinya ada hubungan antara tekanan darah diastolik dengan skor PJK dengan nilai koefisien korelasi sebesar 0.404 yang artinya hubungan berkorelasi lemah, semakin tinggi tekanan darah diastolik, semakin tinggi skor risiko PJK.

3.2.5 Hubungan aktifitas fisik dengan risiko menderita penyakit jantung berdasarkan skor kardiovaskuler Jakarta.

Risiko tinggi PJK lebih banyak didapatkan pada responden dengan aktifitas fisik rendah (78.4\%) dibandingkan dengan responden dengan aktifitas tinggi (11.5\%).

Tebel 4 Hubungan Aktifitas Fisik dengan Risiko PJK di pada Responden di Posbindu wilayah Kerja

Puskesmas Cibeureum Tahun 2019

\begin{tabular}{lccccc}
\hline \multirow{2}{*}{ Aktivitas Fisik } & \multicolumn{3}{c}{ Kategori risiko PJK } & Total & \multirow{2}{*}{ P Value } \\
\cline { 2 - 5 } & $\begin{array}{c}\text { tinggi } \\
(>20 \%)\end{array}$ & $\begin{array}{c}\text { sedang } \\
(10-20 \%)\end{array}$ & $\begin{array}{c}\text { rendah } \\
(<10 \%)\end{array}$ & & \\
\cline { 2 - 5 } & $\mathrm{n}(\%)$ & $\mathrm{n}(\%)$ & $\mathrm{n}(\%)$ & $\mathrm{n}(\%)$ & \\
\hline Rendah & $58(78.4 \%)$ & $16(21.6 \%)$ & $0(.0 \%)$ & $74(100 \%)$ & 0.000 \\
Sedang & $10(66.7 \%)$ & $5(33.3 \%)$ & $0(0.0 \%)$ & $15(100 \%)$ & \\
Tinggi & $3(11.5 \%)$ & $9(34.6 \%)$ & $14(53.8 \%)$ & $26(100 \%)$ & \\
\hline
\end{tabular}

Hasil Uji statistik chi square didapatkan nilai $\mathrm{P}$ value 0.000 yang artinya ada hubungan antara aktifitas fisik rendah dengan risiko PJK.

\subsection{Pembahasan}

\subsubsection{Hubungan Jenis kelamin dengan skor risiko PJK}

Pria memiliki risiko lebih besar terkena serangan jantung daripada wanita, dan pria memiliki serangan lebih awal dalam kehidupan, namun setelah wanita mencapai usia menopause, tingkat kematian wanita akibat penyakit jantung meningkat. Estrogen memiliki efek perlindungan melalui metabolisme glukosa dan sistem homeostatis dan meningkatkan fungsi endotel ${ }^{7}$. Penurunan hormon estrogen alami mungkin menjadi faktor yang meningkatkan penyakit jantung pada wanita sesudah menopause. Estrogen diyakini memiliki efek positif pada lapisan dalam dinding arteri, membantu menjaga pembuluh darah fleksibel mengembang untuk mengakomodasi aliran darah ${ }^{8}$ Hasil penelitian ini menunjukkan Risiko PJK tinggi lebih banyak ditemukan pada responden perempuan dibandingkan pada laki laki hal ini sesuai dengan teori karena umur rata rata responden dalam penelitian ini adalah 53 tahun dan lebih banyak yan6g berjenis kelamin perempuan $(89.5 \%)$. 


\section{Gorontalo Journal Health and Science Community}

Vol : 4, No.1,April 2020

Penelitian ini sejalan dengan penelitian penelitian Nugraha, Nursiswati, dan Rahayu (2018) bahwa adanya hubungan antara jenis kelamin dengan kasus PJK di usia dewasa menengah sampai akhir dimana perempuan lebih berpeluang terhadap PJK dibanding laki-laki, penelitian dilakukan pada pasien PJK berjenis kelamin perempuan rata-rata berusia 59,86 tahun. Perempuan akan berisiko tinggi terhadap PJK apabila telah mengalami menopouse, hal tersebut dikarenakan perempuan mempunyai hormon estrogen yang berfungsi sebagai pelindung imunitas sebelum masa menopause ${ }^{9}$ Berdasarkan hasil penelitian ini dan teori pendukung serta penelitian sebelumnya.

3.3.2 Hubungan umur dengan risiko menderita penyakit jantung berdasarkan skor kardiovaskuler Jakarta.

Sebanyak 87\% orang yang meninggal karena PJK berumur 60 tahun atau lebih. Tingkat kolesterol serum total meningkat dengan meningkatnya umur. Penuaan juga berkaitan dengan perubahan sifat mekanik dan struktur dinding pembuluh darah, menyebabkan hilangnya elastisitas arteri. Umur merupakan faktor risiko penyakit jantung koroner, penambahan umur akan meningkatkan risiko terjadinya penyakit jantung koroner. Semakin tua umur maka semakin besar timbulnya plak yang menempel di dinding dan menyebabkan gangguan aliran darah yang melewatinya. Faktor umur terbukti berhubungan dengan kematian akibat penyakit jantung koroner. Tanda dan gejala penyakit jantung koroner banyak dijumpai pada individu-individu dengan umur yang lebih tua. Faktor umur juga berhubungan dengan kadar kolesterol yaitu kadar kolesterol total akan meningkat dengan bertambahnya umur ${ }^{10}$.

Penelitian yang dilakukan oleh Dongshan Zhu menemukan secara keseluruhan, dari 301438 wanita sebanyak, 12962 (4.3\%) memiliki kejadian penyakit kardiovaskular nonfatal pertama setelah menopause, diantaranya 9369 (3.1\%) memiliki penyakit jantung koroner dan 4338 (1.4\%) memiliki stroke. Dibandingkan dengan wanita yang mengalami menopause pada usia 50-51 tahun, risiko penyakit kardiovaskular lebih tinggi pada wanita yang mengalami menopause dini (usia <40 tahun; HR 1.55, 95\% CI 1.38-1.73; $\mathrm{p}<\quad$ 0. 0001), menopause dini (usia 40-44 tahun; 1.30, 1.22-1.39; $\mathrm{p}<0.0001$ ), dan menopause yang relatif dini (usia 45-49 tahun; 1.12, 1.07-1.18; $\mathrm{p}<0.0001$ ), dengan risiko penyakit kardiovaskular berkurang secara signifikan setelah menopause setelah usia 51 tahun ( $\mathrm{p}<0.0001$ untuk tren). Asosiasi bertahan dalam perokok, dan terkuat sebelum usia 60 tahun untuk wanita dengan menopause dini (HR 1.88, 1.62-2.20; $\mathrm{p}<0.0001)$ dan menopause dini $(1.40,1.27-1.54 ; \mathrm{p}<0.0001)$, tetapi dilemahkan pada usia 60-69 tahun, tanpa ada hubungan signifikan yang diamati pada usia 70 tahun dan lebih tua ${ }^{11 .}$

3.3.3 Hubungan Indeks Massa Tubuh (IMT) dengan risiko menderita penyakit jantung berdasarkan skor

kardiovaskuler Jakarta

Indek Massa Tubuh diatas $25 \mathrm{~kg} / \mathrm{m} 2$ termasuk kategori Obesitas. Obesitas adalah kelebihan jumlah lemak tubuh > $19 \%$ pada laki-laki dan > $21 \%$ pada perempuan atau mempunyai Obesitas dapat meningkatkan tekanan darah, kadar trigliserida, kolesterol, resistensi glukosa, serta penggumpalan darah. Peningkatan tekanan darah membuat pembuluh darah rentan untuk mengalami penebalan dan penyempitan. Hal tersebut jika terjadi pada arteri koroner akan menimbulkan penyakit jantung koroner. Peningkatan kadar trigliserida dan kolesterol pada obesitas akan memicu munculnya thrombosis plak pada pembuluh darah. Hal ini juga dapat menimbulkan penyakit jantung koroner. Obesitas telah muncul sebagai faktor risiko kardiovaskular yang paling potensial dan telah menimbulkan kekhawatiran di antara publik dan masalah kesehatan mereka yang terkait tidak hanya di negara maju tetapi juga di negara berkembang. Hampir 50\% anak-anak yang mengalami obesitas dan kelebihan berat badan di Asia berusia di bawah 5 tahun. Studi epidemiologis dan penelitian telah menunjukkan bahwa patogenesis disfungsi metabolisme terkait obesitas melibatkan pengembangan sistemik, keadaan inflamasi tingkat rendah ${ }^{12}$.

Target keenam dalam rencana tindakan NCD Global adalah untuk mengurangi prevalensi hipertensi $25 \%$. Mengurangi merokok, berat badan, tekanan darah, darah kolesterol, dan glukosa darah semuanya memiliki dampak menguntungkan pada risiko kardiovaskular. Berbagai modifikasi gaya hidup telah ditunjukkan, dalam uji klinis, untuk menurunkan tekanan darah, termasuk penurunan berat badan, aktivitas fisik, mengurangi asupan alkohol, meningkatkan asupan buah segar buah dan sayuran dan mengurangi lemak jenuh dalam makanan, pengurangan asupan natrium makanan, dan peningkatan asupan kalium. Juga, uji coba pengurangan lemak jenuh dan penggantian parsialnya oleh lemak tak jenuh telah meningkatkan dislipidaemia dan menurunkan risiko kejadian kardiovaskular. Peningkatan BMI dapat memprediksi sifat obesitas dan akibatnya dalam hal peradangan dan penyakit lain yang berhubunga $\mathrm{n}$ dengan obesitas ${ }^{12}$. 


\section{Gorontalo Journal Health and Science Community}

Vol : 4, No.1,April 2020

\subsubsection{Hubungan tekanan darah dengan risiko menderita penyakit jantung berdasarkan skor kardiovaskuler Jakarta}

Hipertensi atau tekanan darah tinggi meningkatkan beban kerja jantung, menyebabkan otot jantung menebal dan menjadi lebih kaku. Pengerasan otot jantung ini tidak normal dan menyebabkan jantung berfungsi tidak normal. Ketika tekanan darah tinggi terjadi bersamaan dengan obesitas, merokok, kadar kolesterol darah tinggi atau diabetes, risiko serangan jantung semakin meningkat ${ }^{13}$.

\subsubsection{Hubungan aktifitas fisik dengan risiko menderita penyakit jantung berdasarkan skor kardiovaskuler Jakarta.}

Gaya hidup yang tidak aktif adalah faktor risiko penyakit jantung koroner. Aktivitas fisik yang teratur, sedang hingga tinggi membantu mengurangi risiko penyakit kardiovaskular. Aktivitas fisik dapat membantu mengendalikan kolesterol darah, diabetes, dan obesitas, juga dapat membantu menurunkan tekanan darah pada beberapa orang. Olahraga ringan dapat membantu melepas Nitric Oxide yang dibutuhkan pembuluh darah untuk membuatnya lebih elastis ${ }^{14}$. Direkomendasikan Orang Dewasa setidaknya melakukan aerobic 150 menit per minggu atau 75 menit per minggu untuk aktifitas aerobik berat atau kombinasi keduanya sepanjang minggu. Meningkatkan aktivitas penguatan otot intensitas sedang hingga tinggi (seperti menahan beban) setidaknya 2 hari per minggu. Anak-anak berusia 3-5 tahun harus aktif secara fisik dan memiliki banyak kesempatan untuk bergerak sepanjang hari. Anak-anak berusia 6-17 tahun harus mendapatkan setidaknya 60 menit per hari aktivitas fisik intensitas sedang hingga kuat, sebagian besar aerobik. Menyertakan aktivitas berintensitas tinggi setidaknya 3 hari per minggu. Menyertakan aktivitas penguatan otot dan tulang (menahan beban) setidaknya 3 hari per minggu. Meningkatkan jumlah dan intensitas secara bertahap seiring waktu ${ }^{15}$.

\section{KESIMPULAN}

Variabel yang berhubungan dengan skor risiko PJK adalah jenis kelamin , umur, Indeks Massa Tubuh (IMT) dan tekanan darah dan aktifitas fisik. Perlu penanganan secara menyeluruh dilaksanakan dengan pendekatan five level prevention, yang meliputi promosi kesehatan, diagnosis dini dengan penghitungan IMT, tekanan darah dan pengobatan yang cepat dan tepat, pembatasan kecacatan bagi skor risiko tinggi

\section{UCAPAN TERIMAKASIH}

Penulis mengucapkan terima kasih kepada Lembaga Penelitian dan Pengabdian masyarakat Universitas Siliwangi yang telah memberikan hibah PenelitianPengembangan Kapasitas(PPKap). Kepala Puskesmas Cibeureum Kota Tasikmalaya yang telah memberikan ijin penelitian serta seluruh peserta Pos pembinaan Terpadu (Posbindu) yang menjadi responden dalam penelitian ini. 


\section{Gorontalo Journal Health and Science Community}

Vol : 4, No.1,April 2020

\section{DAFTARPUSTAKA}

1. https://www.heart.org/en/health-topics/consumer-healthcare/what-is-cardiovasculardisease/coronary-artery-disease Diakses 21 April 2019).

2. Kemenkes, 2018, Hasil Utama Riskesdas 2018, Kementerian Kesehatan Badan Penelitian dan Pengembangan Kesehatan.

3. https://rsud.tasikmalayakota.go.id/2019/03/27/mengenal-penyakit-jantung-koroner-pjk/).

4. https://www.heart.org/en/health-topics/heart-attack/about-heart-attacks Diakses 21 April 2019).

5. Kemenkes, 2017, Petunjuk Teknis Penatalaksanaan Penyakit Kardiovaskular Untuk Dokter, Kementerian Kesehatan RI Sekretariat Jenderal Pusat Kesehatan Haji Tahun 2017.

6. Kusmana D. (2017), Cardiac Prevention and Rehabilitation. Retrieved 12 April 2017 from docshare.tips.

7. https://www.heart.org/en/health-topics/heart-attack/understand-your-risks-to-preventaheart-attack.

8. https://www.heart.org/en/health-topics/consumer-healthcare/menopause-and-heart-disease Diakses 21 April 2019.

9. Andri Nugraha1 ), Nursiswati2 ), Urip Rahayu2 ), Faktor - Faktor Risiko Penyakit Jantung Koroner Pada Pasien Wanita Di Poliklinik Jantung Rumah Sakit Dr. Slamet Kabupaten Garut, jkh/ Volume 2/ Nomor 2/Juli 2018 (Issn: 2548-1843, Eissn: 2621-8704).

10. https://www.heart.org/en/health-topics/heart-attack/about-heart-attacks Diakses 21 April 2019.

11. Dongshan Zhu, 2019, Age at natural menopause and risk of incident cardiovascular disease: a pooled analysis of individual patient data, Lancet Public Health 2019; 4: e553-64 Published Online October 3, 2019 https://doi.org/10.1016/ S2468-2667(19)30155-0,Australia

12. Kumar M. R., Shankar R., Singh S, 2016, Hypertension Among The Adults In Rural Varanasi: A Cross-Sectional Study On Prevalence And Health Seeking Behavior. Indian Journal of Preventive and Social Medicine. 2016;47(1-2):78-83. [Google Scholar].

13. Https://www.heart.org/en/health-topics/heart-attack/understand-your-risks-to-prevent-a-heart-attack.

14. Winzer, 2018 Physical Activity in the Prevention and Treatment of Coronary Artery Disease Journal of the American Heart Association 1, DOI: 10.1161/JAHA.117.007725.

15. https://www.heart.org/en/healthy-living/fitness/fitness-basics/aha-recs-for-physical-activityinfographic). 